Globus Journal of Progressive Education

A Refereed Research Journal

Vol 10 / No 1 / Jan-Jun 2020

ISSN: 2231-1335

\title{
SUSTAINABLE DEVELOPMENT BY PUBLIC PRIVATE PARTNERSHIP: A MOVE TOWARDS QUALITY ENHANCEMENT IN EDUCATION
}

\author{
*Dr. Bhawna
}

\begin{abstract}
Public Private Partnership has been the buzzword in policy debates on development strategies. There are many questions that need to be critically examined in this context. What is public-private partnership? How does it work in the case of education sector? Is it new model? What are the strengths and weakness of the PPP as a development strategy? Many researchers have explored the applications of PPP to improve the efficiency of infrastructure delivery. This study aims to review the existing PPP research to explore the status quo, trends and gaps in research for PPP infrastructure projects. A systematic process involving a three -phase word frequency analysis, cluster analysis and a search on potential research topics helps us to provide enough potential articles related to PPP research and reduce arbitrariness and subjectivity involved in the research topic analysis. While examining the implications for educational development, the author presents a critical review of some of the somewhat familiar and some not so familiar arguments. He examines some of the baffling questions, highlighting the possible ramifications of PPP for education Development in India, partly drawing from the limited experience of the emerging and prevailing diverse models of PPP in India and abroad.
\end{abstract}

Keywords: Public Private Partnership, PPP, Education, Quality, Sustainable.

\section{Introduction}

Public and private partnership has been the latest mantra of development. It has also become a fashionable slogan in the development strategies, particularly during the last couple of decades in many developing as well as advanced countries. Though the practice of PPP is not altogether a new phenomenon, it has become popular in neo-liberal era, assuming high magnitude in the one hand, entering sectors that have had hitherto been reserved for public monopoly, and on the other hand, taking different forms which were until recently unknown. Even those countries which prohibited any role of the private sector for long have become the receptive idea of PPP and even are championing the cause of private sector and PPP in most developing activities. PPP is being adopted in a number of economies in various infrastructure development sectors such as developments of airports, railways roads and so on. But it is no longer confined to these sectors. Education is the only sector which had been to the exclusive jurisdiction of the state for long. But PPP is being extended to education, including elementary education which is regarded as a universal human/fundamental right and also other human development sectors such as health and even to activities relating to poverty reduction. Recent experience has shown that the role of the private sector in sectors such as education and health has been producing mixed effects, more than negative effects on quality, equity and other dimension of education. Instead of direct provision by private sector, PPP is depicted as if it is different from privatization, and as a viable strategy.

This paper aims to shed light over these and grey areas of the PPP debate-namely, meaning, rationalities, policy options and effects - with a focus on educational provision. It also aims to unpack PPPs as a complex policy category and to reflect on its different translations and implications in education. Finally, the paper argues that PPPs are challenging policy category in education, and that not all PPP policy options are equally appropriate to achieve the expected goals (including cost effectiveness, equity, innovation and

*Psychology Teacher, R.P.S. International School, Rewari, Haryana, India. Email: sangeety@ gmail.com 
so on) in all types of educational settings.

There are many questions with hypothesis that need to be critically examined in this context. What is publicprivate partnership? How does it work in the case of education sector? Is it new model? What are the earlier practices that come close to this kind of models? What are the strengths and weakness of the PPP as a development strategy?

While examining the implications for education development, it is also necessary to underline at the very outset that the education system in India is more privatized than in many other advanced countries of the world, and the rate of growth of the private sector in education is increasing at an alarming rate.

Among the earlier models, the government aided private schools system, for instance in India can be described as a model of PPP. This model involved setting up a school or college by a nonprofit organization and in few cases business entity, with its own funds and running the school by the same body for a minimum number of years before it becomes eligible for government aid for recurring expenditureessentially ,but not exclusively salary expenditure of the staff. These institutions are subject to government regulations; they are to follow most of the government rules and regulations in terms of admissions, fees and scholarships, other incentives and subsidies, recruitment of staff, salary structure, etc. In effect, they are considered as no different from public institutions, but for the management of the institution of the private sector. These schools were often funded by the government up to 95 percent of the recurring and sometimes also a part of non- recurring expenditure. Because of some of the malpractices indulged in by school management, many of them were taken over by the government, or the staff directly paid its salaries by the government, or the staff direct paid its salaries by the government. But this has been a very prominent model in many countries both at school level and at higher education. For example, private nonprofit schools in country where government pays all costs of these private schools, or charter schools in USA, which are private schools, operate under contract with government and are publicly funded on per student basis, come close to the aided schools in India and in many other countries are not.

In fact, other private schools may also come under this category of PPP as these schools, which do not receive direct financial support from the state, do nevertheless receive indirect subsidies in the form of land at concessional prices tax concessions on other activities they are also, of course, not described as models of PPP.
The academic literature on education PPPs, overwhelmingly dedicated to compulsory education, can rough divided in three main streams, which overlap with the health typology proposed above. The first stand examines PPPs as policy model (for instance, Robertson et al., 2012). The second groups of works looks at the role of transnational actors and epistemic communities in the emergence of education PPPs (for instance Mundy \& Menashy, 2012; Vanfleet, 2012; Verger, 2012). The third stream is focused on concrete interventions in the field, mainly demand - side financing schemes, and to a lesser extent, contract /charter schools. This literature focuses on South Asia (India and Pakistan) and Latin America, especially Chile and Columbia where two large-scale voucher programs have been implemented (fir instance Mc Ewan \& Carnoy, 2000 or Quezada Hofflinger, 2008).

\section{Public Private Partnerships (PPP) in Education}

The term public -private partnership (PPP) is a loose term used to refer to a wide range of contractual agreements between public institutions and the private sector. Public private partnership's (PPPs) are phenomenon in many countries, regardless of income, but they have been growing in low-middle income countries in recent years. Public -private partnership (PPP) has become a fashionable slogan in new development strategies, particularly over the last couple of decades. It is projected as an innovative idea to tap private resources and to encourage the active participation of the private sector in national development.

The PPP model proposed in the eleventh plan provides for no government or social control over education. It will lead to the privatisation and commercialistion of education using public funds.

In the case of education, PPP has been proposed as an important strategy in the $11^{\text {th }}$ five year Plan. Among many things, the $11^{\text {th }}$ plan has proposed the setting up of 6000 new model schools in secondary education, affiliated to the Central Board of Education. Of these 2,500 are to be under the PPP model. The intention is to set up these schools on the backward regions and remote areas where good schooling facilities do not exist, so that quality education is accessible in the backward region as well.

According to the model finalized by the Planning Commission in consultation with the private sectors, these schools will be set up by 2014 and will have the capacity to educate 65 lakh students, of whom 25 lakh 
will be from the deprived sections. Each school will have about 2,500 students, 1,000 students from the scheduled castes, the Scheduled Tribes and other Backward Classes. They will be required to pay a monthly fee of Rs.50 a month. The remaining costs of these students estimated to be Rs 1,000 to Rs 1,200 a head per month will be reimbursed by the union government to the schools. It is estimated that the government will have to pay Rs10,500 crore until 2017. The amount is likely to go up with escalating prices, in general, and increasing costs of education in particular.

Over and above this, the schools may get access to relevant funds from the Centre and the State governments under different schemes. The schools will be free to admit anyone to the remaining 1,500 seats and charge any amount of fee.

Areas that come under PPP might include almost every aspect of education ,including policy making, formulations of plans, evaluation and implementation, ownership, management, funding, running of institutions, academics aspects, special academics aspects, examination including entrance examinations, support services, hostels, healthcare, transport, maintenance, security, and so on, though policy formulation is normally considered as an exclusive prerogative of the state.

In fact, other private schools, may also come under this category of PPP, as these schools, which do not receive direct financial support from the state, do nevertheless receive indirect subsidies in the form of land at concessional prices and tax concessions in other activities. They are also, of course, not described as models of PPP.

Human capital contracts under which the education of selected students is financed by corporate sector under a contract that once graduated, they work for the given corporate sector, and many models of mixed financing of education would qualify to be regarded as various models of PPP.

\section{PPP Arrangements}

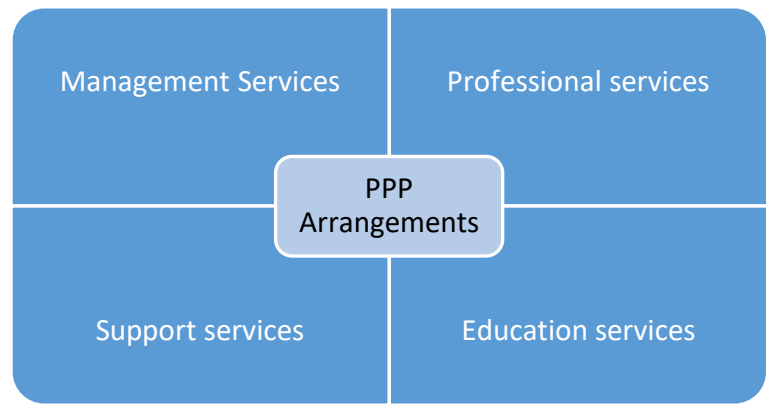

(1) Management Services:- Management of either a single public or an entire public school district by private organisations. The responsibilities that the contractor assumes under these contracts usually fall unto four categories: Financial management, Staff management, and Long.-term planning and leadership. Within these contracts, all non-managerial personnel continue to be public sector employees.

Example:- Educomp has entered into an agreement with the Government of Punjab in running five Senior Secondary Schools in Punjab state under PPP model.

(2) Professional Services:- It involves Contracting out professional services such as teacher training, textbook delivery, curriculum design, quality certification, and supplemental services. Its main advantage is that its brings private providers expertise. The quality of service can be specified in the contract and sanctions included if the contractor fails to provide that level of quality. Thus the performance of contractors can also be conveniently monitored. A prime example of this form of PPP is provided by the Government of Gujarat's (GoG) recent steps to improve the level of learning in its schools across the state. The GoG put out tenders to private operators to assist in the delivery of a number of projects focusing exclusively on improving the quality of education and /or building capacity of teachers and educational personnel.

(3) Support Services:- It involves contracting out Non instructional activities, including building maintenance, pupil transportation and schools meals ,IT facilities,laboratory, which is often very costly for public schools.

Examples: IT services are being provided in several government schools in several states like TamilNadu, Karnataka and Andhra Pradesh by private partners who set up the entire hardware infrastructure along with facility management.

(4) Educational Services:- Instead of engaging a private organization to operate a public school, some governments contracts out the enrolment of students in private schools. By paying for students to enroll in existing schools, governments can quickly expand access without incurring any up front expenditure on constructing and equipping new schools.

(5) Provision of Infrastructure:- Government can contract out the financing and construction of facilities to the private sector which allows the government to pay for these capital investments over time by making periodic payments over the term of the contract. 


\section{Key Features of Public-Private Partnerships in Education}

PPPs are becoming an increasing feature in education, with well-known and emerging models including the outsourcing of both educational and non-educational support services, voucher schemes and charter schools. While formats can vary considerably, some of the common features are as follows.

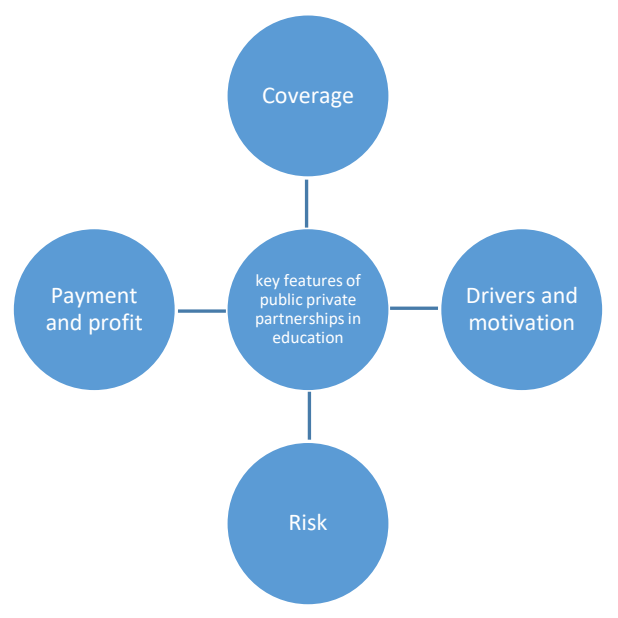

(1) Coverage:- PPPs in education focused initially on physical infrastructure and construction, but have increasingly moved into the provision of services ,including support services such as transportation, meals, cleaning or maintenance and extending into direct provisions of education services such as the supply of textbooks, curriculum development, teacher training, student assessments or even full operation of schools such as "charter schools voucher schemes are where a government provides funds to the fees of individual students at private schools chosen by their family."

(2) Drivers and Motivations:- What drives the expansion of PPPs in education, as a policy choice for governments, varies greatly .Private actors can be motivated by profit, philanthropy or corporate social responsibility. They can range from local entrepreneurs to global corporations.

(3) Risk:- The partnership is usually intended to involve form of risk sharing, Governments, however, often provide a guarantee that any upfront costs taken on by the private provider will make a profit over the lifetime of the contract. In fact as, some commentators point out, and there is often a fundamental tension between public accountability and commercial orientation.

(4) Payment and Profit:- The private company usually gets paid over a number of years, either through guaranteed charges paid by users, payments from the government, or a combination of both. A single PPP contract often serves as a shrewd business opportunity for a private entity, providing a flow of income, often serves as a shrewd business opportunity for a private entity, providing a flow of income, often for decades, largely underwritten by the government particularly where the government remains the duty.

\section{GCE's Concerns about Education PPPs}

Critics of PPPs point out them can be a dangerous diversion from delivering quality and equitable education and lifelong learning for all. GCE is particularly concerned about the growth of PPPs in education, and the impact on the achievement of the right to education, specifically:

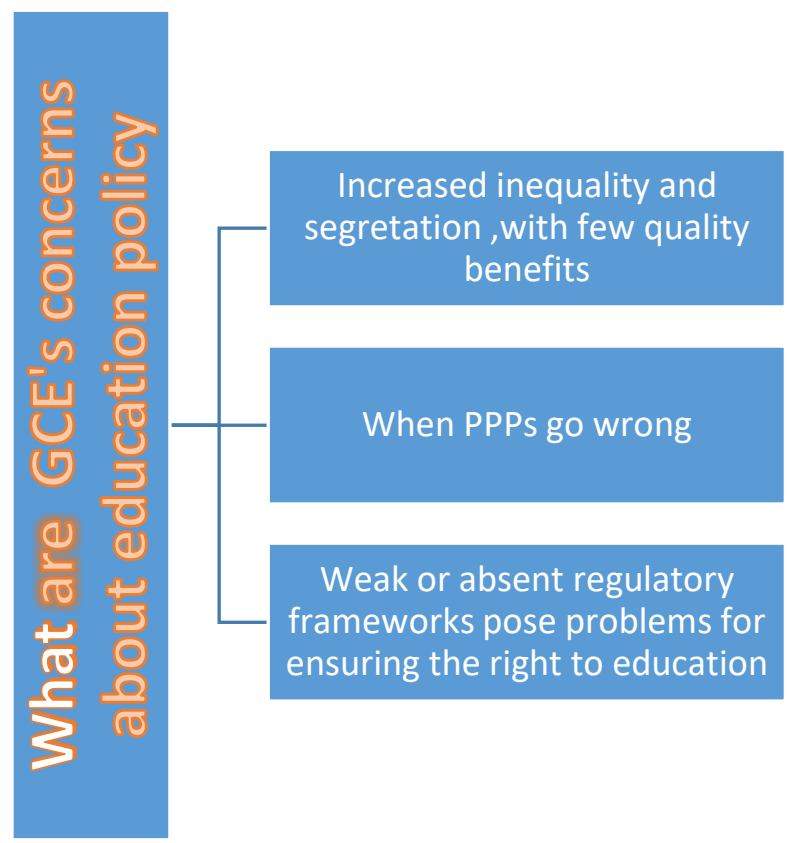

(1) Increased Inequality and Segregation, with Few Quality Benefits:- Certain PPPs, notably private provision of schools, have been shown to lead to systematic inequality and segregation, in which schools of different quality cater to different socioeconomic groups, often, with little or no overall quality improvements. This contributes to inequality, social segregation and greater social stratification, 
undermining the role education plays as a public good. This has been shown to be a particular concern through the use of voucher and charter schools.

(2) When PPPs go wrong:- As stated international human rights law, government remain the ultimate guarantor of the right to education, such that they retain responsibility and bear the costs of any risk-in case of failed PPPs. This point to the limits of the underlying principle of risk sharing between the public and private sectors, embedded in PPP in education: if services fail the state must step-in to redress (often costly) problems. This is ultimately a cost which is shouldered by citizens themselves who, through their taxes, must pay to ensure the state can fulfill the responsibility to provide education for all.

(3) Weak or About Regulatory Frameworks Pose Problems for Ensuring The Right to Education:PPPs must have a robust regulatory framework to ensure the private providers adhere to norms and standards of quality, transparency, public accountability, and oversight. The capacity of states to effectively regulate is vital to securing the right to education, and to effectively mitigating against inequality. However state capacity (or willingness) to set, monitor, and regulate private providers, particularly in low income or fragile contexts with governance issues, has been shown to be limited. Moreover education systems in many countries are increasingly being opened up to profit making and trade with especially in weak regular environments, private and commercial interests increasingly involved in agenda setting as well as provision.

\section{Conclusion}

Due to the growing interests in research and application of PPP procurement, this study presented a detailed review of the status, sustainable development gaps and research suggestion for the future of PPP research for infrastructure projects in education sector. In addition, relationship between research groups is analyzed, based on the theoretical foundations framework. The findings can provide some conclusions on the status of PPP research and guide researchers in selecting the research topic in the future.

Although the current study contributes to the literature on PPP infrastructure projects research and sustainable development projects in education by summarizing research topics and exploring research gaps, it also has some limitations that need to be addressed by conducting further research.

\section{References}

1. DISE. "Elementary Education in India: Analytical Report 2005”. District Information System for Education, NIEPA, New Delhi, 2006.

2. Educational International. Public-Private Partnerships in Education. Brussels; Education, 2009.

3. PrathamASER 2005 - Annual status of Education Report. Pratham, New Delhi, 2006.

4. Pratham. ASER 2006 - Annual status of Education Report. Pratham, New Delhi, 2007.

5. World Bank. Secondary Education in India: Investing in the Future. Human Development Unit, South Asia Region, World Bank Draft, 2006.

6. World Bank. Public - Private Partnerships in Education, 2011;

http://web.worldbank.org/WBSITE/EXTER NAL/TOPICS/EXTEDUCATION/O.,conten tMDK:20756247 menuPK :2448342 page PK:210058 piPK:210062 the SitePK: 282386,00.html

7. Kumar, Puneet. "Impact of Education on Consumer Behavior with Social Change". 2003; Indian MBA.com.

8. Agarwal, Nidhi; Gupta Jayanta Das. "School Effectiveness in The Development of High School Children". International Journal of Academic Research and Development, 2018, 3(4), 200-202; doi:10.5281/zenodo.3806990.

9. Agarwal, Nidhi; Pundir Neelam. "A Study of Personality Traits of B.Ed. Students". Learning Community- An International Journal of Educational and Social development, 2016, 7(2), 127-131; doi: 10.5958/2231-458X.2016.00013.0.

10. Agarwal, Nidhi; Shiju P.S. "A Study on Content Generation for Internet Usage". International Journal of Advanced Research and Development, 2018, 3(2), 1380-1382; doi: 10.5281/zenodo.3764806. 